\title{
Significance of Symbiotic Associations in Sustainable Agriculture and Animal Nutrition
}

\author{
Dande KG* \\ Department of Dairy Science, India \\ *Corresponding author: Dr. KG Dande, Department of Dairy Science, Mahatma Basweshwar College, Latur, India
}

Submission: April 23, 2018; Published: February 05, 2019

\begin{abstract}
Symbiosis (originated from Greek word "symbiosis" which means 'a living together') is any type of a intimate and long-term biological association between two or more dissimilar biological organisms. The organisms, each termed a symbiont, may be of the same or of different species. Mutualistic symbiosis is a type of symbiosis which results in the benefit of all the organisms that maintain intimate interaction through either natural or man-made associations. The association of nitrogen fixing bacteria and legume plants or rumen micro-organisms and ruminants are natural due to their role in ecosystem. Humans, by engaging in plant agriculture and animal agriculture have also developed relationships with plants and animals, which can be described as permassociation i.e. Permanent Association. This relationship developed by human beings intensifies the biodiversity of plant and animal species on earth sustaining living ecological systems and/or cycles. It also enhances the health of soil, plants and animals managed under precautionary and responsible manner to protect the health of current as well as future generations and the environment. This is achieved by the appropriate design of management of biological processes based on ecological systems using natural resources. An example of such emerging associations are tribal farmers in India with their sheep and goat. Symbiotic relationship and environment synchronization develop much closure association. Feed efficiency is a measure to know how the farm animals convert the nutrients that they eat in to the product. Considerations of Temperature humidity Index, Feed efficiency of animals and the efforts of human for environment synchronization results in better sustainability in animal agriculture.
\end{abstract}

Keywords: permassociation; Symbiotic relationship; Environment synchronization; Feed efficiency

\section{Introduction}

Symbiosis means living together in an intimate association of two or more dissimilar organisms. Parasitism, commensalism and mutualism are the three types of symbiotic relationship. Out of these three, in mutualytic symbiosis both the organism in association get benefited, both are in permassociation (Permanent Association) and interdependent. A site-specific application in an integrated system of plant and animal product practices is sustainable agriculture that enhances environmental quality and natural resource base which promotes stable, prosperous farm families and communities. The term symbiosis was used by Anten De Bary (1879), a German mycologist at the university of Strasbourg to refer to the living together or close association of two different species. Mutualistic symbiotic relationships and sustainable plant and animal agriculture may be naturally controlled or man-made.

Naturally controlled symbiosis and base for sustainable agriculture

Symbiotic relationship may be between soil, plant and animals associated together where all organisms get benefited and are interdependent. Nature has evolved all symbiotic relationships between the organisms of permassociation, which became the natural resource base for sustainable plant or animal agriculture.

\section{Evolution and symbiosis}

Nature's first symbiotic permassociation is evolutionary origin of chloroplast and then the mitochondria of all eukaryotic cells. It was believed that both were free living bacteria that became incorporated in primitive host cell [1]. Microbial symbiosis performs many chemical reactions which are not possible for their host and create the basis for sustainable plant or animal agriculture collectively. They can photosynthesize, fix nitrogen, synthesize amino acids, provide vitamins and growth factors and remain in permassociation. (Permanent Association). Plants cannot metabolize the molecular nitrogen in the form of nitrate converted to NH4+. Legumes overcome this problem by their semiotic union with a group of nitrogen fixing bacteria, Rhizobia. It is the natures gift that each legume plant species has permassociation with a specific nitrogen fixing bacteria. These bacteria live in a specialized root nodule.

\section{Microbes and animals permassociation}

Evidence is accumulating that, interactions of animals with environmental microbes have resulted in the coordinate evolution of a complex symbiosis. Co-evolved partnership between microorganisms and animals represent a common fundamental theme in the biology of animals. Most environmentally transmitted symbiosis in the animals is establishment of rumen micro-organisms. The ruminants like cattle, buffalo, sheep, Goat cannot digest their feed. The various types of microbes get established in a perm association in the ruminant's stomach (Table $1 \& 2$ ). These microbes digest the feeds ingested by ruminants which will result in the production of food necessary for human. Microbes get nutrients and a place to live in the alimentary canal, whereas the host ruminant gets benefited as these microbes assists them in digestion of feed. 
Table 1: Establishment of bacteria.

\begin{tabular}{|c|c|c|}
\hline Sr. No. & Organisms & At Age \\
\hline 1 & Lactic acid bacteria & 1 to 6 weeks \\
\hline 2 & Cellulolytic Bacteria & After 3 weeks \\
\hline 3 & Facultative anaerobes & 3 to 6 weeks \\
\hline 4 & $\begin{array}{c}\text { Other types of } \\
\text { bacteria found in } \\
\text { mature animal } \\
\text { All types of microbes } \\
\text { predominantly as that } \\
\text { of mature animal }\end{array}$ & After 13 weeks \\
\hline 5 & \multicolumn{2}{|c|}{} \\
\hline
\end{tabular}

Table 2: Microbial count in rumen liguor (per $\mathrm{ml}$ ).

\begin{tabular}{|c|c|c|c|}
\hline $\begin{array}{c}\text { Types of } \\
\text { Organism }\end{array}$ & Buffalo & Cow & Sheep/Goat \\
\hline $\begin{array}{c}\text { Total Bacterial } \\
\text { Count (Direct } \\
\text { microscopic) } \\
\text { *1010 }\end{array}$ & 6.9 to 32.7 & 5.4 to 31.4 & 18.0 to 88.0 \\
\hline Protozo**104 & 1.8 to 13.8 & 0.3 to 19.7 & 1.4 to 7.8 \\
\hline Yeasts*103 & 6.9 to 18 & 00 to 10 & 6.8 to 13 \\
\hline
\end{tabular}

\section{Manmade symbiotic permassociation and sustainable} plant and animal agriculture

Mutualistic symbiotic permassociation may be between soil, plant, animals and human associated together where all the organisms get benefited and an interdependent. Our genus Homo has been on earth from about two million years ago. Out of this time span, almost $99.5 \%$ lived in a history of subsistence on hunting the animals and gathering food. It was totally dependent on nature for life support. About 10,000 years ago, the transition from hunting to foraging for food to the cultivation of plants and domestication of animals took place. Humans have used their intellectual advantage and developed permassociation (Permanent Association) with plants as well as animals. However, their relationship has elements of symbiosis can be seen in the world as plant husbandry and animal husbandry. Number of plant and animal species were get spread throughout the world from their original habitat.

The diversity of plants, animals and microbes on earth abounds due to evolution, climate competition and symbiotic relationship developed by human. At each new kingdom of life came out, the ecosystem on earth, became more complex and the biotic components became more interactive. The droppings of sheep, and goat contains higher nutrients than FYM and compost. As a traditional method in Maharashtra State of India, the Sheep and goat are kept in the open cultivated land. Their droppings and urine get mixed in the soil which facilitates to increase the soil NP \& K Proportions, also helps the soil microbes for enrichment of soil fertility (Table 3). Field trials conducted at IISS, Bhopal [2,3] indicated that continuous application of organic manures (Amount varies from 3 to 6 tons/hectare according to source) resulted, not only sustainable crop productivity but also increased the soil nutrient level than chemical fertilizer Table 3.

Table 3: Effect of organic manure $\mathrm{V} / \mathrm{s}$ chemical fertilizer.

\begin{tabular}{|c|c|c|c|}
\hline \multirow{2}{*}{ Treatment } & \multicolumn{3}{|c|}{ Soil Available } \\
\cline { 2 - 4 } & $\begin{array}{c}\text { Nitrogen (N) } \\
\text { (kg/ha) }\end{array}$ & $\begin{array}{c}\text { Phosphorous } \\
\text { (P205) (kg/ } \\
\text { ha) }\end{array}$ & $\begin{array}{c}\text { Potash (K)(kg/ } \\
\text { ha) }\end{array}$ \\
\hline Initial & 132 & 12.4 & 560 \\
\hline Poultry excreta & 161 & 25.1 & 658 \\
\hline Cattle dung & 151 & 19.1 & 621 \\
\hline $\begin{array}{c}\text { Chemical } \\
\text { Fertilizer }\end{array}$ & 143 & 15 & 579 \\
\hline
\end{tabular}

\section{Significance in animal nutrition}

Feed efficiency is a measure to know, how the farm animals convert the nutrients they eat into products. On the most basic level, it gives an idea, how closely a ration meets an animal nutrient requirement and of the relative demands of maintenance and production. Symbiotic demassification and environment synchronization developed much closure association between plants, animals and human which benefit all those associated.

Calculation for feed efficiency (FE)

$\mathrm{FE}=$ Average milk $(\mathrm{kg}) /$ Average DMI $(\mathrm{kg})$

$\mathrm{FE}=$ Average weight gain $(\mathrm{kg}) /$ Average DMI $(\mathrm{kg})$

Where,

$\mathrm{FE}=$ Feed Efficiency

DMI=Dry Matter Intake

\section{Feed efficiency in nondescript cows}

Twelve non-descript cows of first lactation were kept under three digestion trials each with pre-experimental period of 21 days and experimental period of 7 days cows fed with concentrate mixture and roughages along with $1.0 \%$ of the concentrate mixture, poultry excreta are added to the ration at Gorakshan Santhal (NGO) in Latur city (MS, INDIA). Poultry excreta is kept in autoclave to kill the microbes if any and then fed before milking in the morning and evening hours mixed with small quantity of dry roughage and studied the feed efficiency under different season along with the practices necessary for environment synchronization under different housing conditions as shown in Table 4.

The results (Table 4) indicates thatenvironmentsynchronization and poultry excreta increase feed efficiency for weight gain as well as milk production under loose housing conditions [4] described microclimate in some other types of houses for cows provide animal comfort by providing cooler atmosphere conditions which improves productivity. 
Table 4: Effect of feeding and environment synchronization on feed efficiency of cow.

\begin{tabular}{|c|c|c|c|c|c|}
\hline Parameters & $\begin{array}{l}\text { Type of } \\
\text { Housing }\end{array}$ & Control Tree Shed & $\begin{array}{l}\text { Summer Season Control } \\
\text { Tree Shed Thatched } \\
\text { Material Animal Given } \\
\text { with Cold Water Poultry } \\
\text { Excreta }\end{array}$ & $\begin{array}{l}\text { Winter Season Thatched } \\
\text { Material Animal Given with } \\
\text { Warm Water Poultry Excreta }\end{array}$ & Overall \\
\hline \multirow{3}{*}{ Daily weight gain(kg) } & S & 0.115 & 0.384 & 0.365 & 0.375 \\
\hline & $\mathrm{S}+\mathrm{O}$ & 0.128 & 0.392 & 0.569 & 0.481 \\
\hline & LH & 0.13 & 0.524 & 0.372 & 0.448 \\
\hline \multirow{3}{*}{$\begin{array}{l}\text { Dry matter intake/ } \\
\mathrm{kg} / \text { day/head }\end{array}$} & $\mathrm{S}$ & 2.891 & 6.432 & 7.485 & 6.94 \\
\hline & $S+0$ & 2.102 & 5.869 & 7.29 & 6.565 \\
\hline & $\mathrm{LH}$ & 2.098 & 5.11 & 7.19 & 6.145 \\
\hline \multirow{3}{*}{$\begin{array}{l}\text { Feed efficiency } \\
\text { weight gain/DMI } \\
(\mathrm{kg})\end{array}$} & S & 0.039 & 0.059 & 0.049 & 0.054 \\
\hline & $\mathrm{S}+\mathrm{O}$ & 0.06 & 0.067 & 0.078 & 0.073 \\
\hline & $\mathrm{LH}$ & 0.061 & 0.102 & 0.051 & 0.073 \\
\hline \multirow{3}{*}{ Milk yield kg/day } & $S$ & 2.15 & 6.4 & 6.5 & 6.45 \\
\hline & $\mathrm{S}+\mathrm{O}$ & 2.2 & 7.13 & 7.48 & 7.31 \\
\hline & $\mathrm{LH}$ & 3.15 & 8.15 & 8.85 & 8.5 \\
\hline \multirow{3}{*}{$\begin{array}{l}\text { Feed efficiency milk } \\
\text { yield/DMI kg }\end{array}$} & S & 0.74 & 0.995 & 0.868 & 0.929 \\
\hline & $\mathrm{S}+\mathrm{O}$ & 1.04 & 1.214 & 1.026 & 1.113 \\
\hline & $\mathrm{LH}$ & 1.5 & 1.594 & 1.23 & 1.383 \\
\hline
\end{tabular}

\section{Feed efficiency in crossbred cows}

Twelve lactating cross bred Holder cows (62.5\% cross) of third and fourth lactation were selected and maintained under different housing conditions for 21 days each as shown in Table 5. The cows were fed with concentrate mixture and roughages in the proportion of 60:40 respectively. In addition to that they were fed with $250 \mathrm{gms}$ of butter milk mixed with 250 gms dry roughage and fed before morning and evening milking. The studies were carried out to know the feed efficiency along with certain physiological parameters as shown in Table 5 during summer months.

Table 5: Effect of feeding and environment synchronization in crossbred cows in summer season.

\begin{tabular}{|c|c|c|c|c|}
\hline Parameters & $\begin{array}{c}\text { Tree shed (No butter } \\
\text { milk) }\end{array}$ & $\begin{array}{c}\text { Loose house Showering } \\
\text { cold water alone + butter } \\
\text { milk }\end{array}$ & $\begin{array}{c}\text { Loose house drinking cold } \\
\text { water alone + butter milk }\end{array}$ & $\begin{array}{c}\text { Loose house showering } \\
\text { drinking cold water } \\
\text { sprinkling cold water + } \\
\text { butter milk }\end{array}$ \\
\hline Ambient Temp. $\left({ }^{\circ} \mathrm{C}\right)$ & 40 & 39 & 39.4 & 38 \\
\hline Respiration rate per min. & 40 & 32 & 34 & 34 \\
\hline Heart rate per min & 60 & 52 & 48 & 34 \\
\hline Body temp. $\left({ }^{\circ} \mathrm{C}\right)$ & 39.1 & 38.9 & 38.7 & 38.4 \\
\hline $\begin{array}{c}\text { Daily dry mater intake kg/ } \\
\text { head/day }\end{array}$ & 11.88 & 10.9 & 10.14 & 9.24 \\
\hline Milk yield kg/day/head & 8.66 & 10.24 & 10.5 & 11.3 \\
\hline Feed efficiency & 0.728 & 0.94 & 1.03 & 1.22 \\
\hline
\end{tabular}

\section{Conclusion}

Table 5 indicate that animal responses like rectal temperature, respiration rate, heart rate under different housing conditions were well with norms in lactating cows [5]. The feed efficiency increased with low dry matter intake. Considerations of temperature humidity index (heat stress), feed efficiency of animals and efforts of human for environment synchronization results in butter sustainability in plant and animal agriculture [6,7]. Appropriate, well planned design and management of biological processes based on ecological systems using natural resources, which are the internal to the systems also referred agro-ecological methods caused to develop permassociation among the symbionts. Biodiversity is good for plant and animal agriculture and plant and animal agriculture is good for biodiversity.

\section{References}

1. Gray MW (1992) The endosymbiont hypothesis revisited. Int Rev Cytol 141: 233-357.

2. Ramesh P, Panwar NR, Ramana S, Singh AB (2006) Organic soyabean production. Extension Bulleting No. 1/2006. Indian Institute of Soil Science, Bhopal, India, p. 21. 
3. Bhat PN, Menon KKG, Srivastava HC (1989) Animal productivity pub. Oxford and IBN Publishing Co Pvt Ltd, New Delhi, India.

4. Mathura MS, Sengupta BP, Roy H (1963) Physiologic reactions of buffalo cows maintained in two different housing conditions during summer months. Indian J Dairy Sci 16: 203-215.

5. Benpong IA (1983) Effect of shelter and sprinkling on the performance of lactating cross bred cow. MSc Thesis, Hissar, Haryana, India.
6. Behl RK, Singh DP, Tomar VS, Bhale MS, Khare D, et al. (2009) Sustainable agriculture for food, bioenergy and livelihood security. Agrobios, Rajasthan, India.

7. Margulis L (1992) Symbiosis and cell evolution Pub. WH Freeman and Co San Francisco, California, USA.

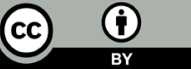

Creative Commons Attribution 4.0 International License

For possible submissions Click Here

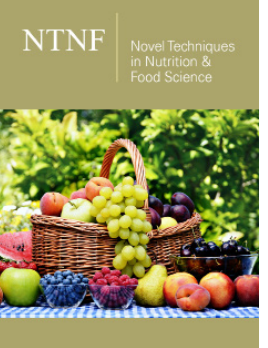

Novel Techniques in Nutrition and Food Science

\section{Benefits of Publishing with us}

- High-level peer review and editorial services

- Freely accessible online immediately upon publication

- Authors retain the copyright to their work

- Licensing it under a Creative Commons license

- Visibility through different online platforms 